COLLEGE CLASSICS IN ENGLISH

General Editor

H. NORTHROP FRYE

回 


\title{
JOHN STUART MILL
}

\section{A SELECTION OF HIS WORKS}

\author{
Edited by \\ JOHN M. ROBSON \\ Victoria College \\ University of Toronto
}

Macmillan Publishers Limited 
ISBN 978-1-349-81782-5 ISBN 978-1-349-81780-1 (eBook)

DOI 10.1007/978-1-349-81780-1

\section{(c) MACMILLAN PUBLISHERS LIMITED 1966}

Reprint of the original edition 1966

All rights reserved - no part of this book may be reproduced in any form without permission in writing from the publisher, except by a reviewer who wishes to quote brief passages in connection with a review written for inclusion in a magazine or newspaper.

Library of Congress Catalogue Card No. 66-19868 


\section{Contents}

Introduction / vii

Note on the text / xxix

Biographical data / xxxii

On Liberty / 1

Utilitarianism / 149

From Autobiography / 229

AN ECONOMIC AND SOCIAL FORECAST, from

Principles of Political Economy / 321

THE LOGIC OF MORALS, from System of Logic / 343

From The Subjection of Women / 357

ON EDUCATION, from Inaugural Address at

St. Andrews University / 379 
SELECTED READINGS

On Intellectual Humility / 422

On Poetry / 422

On Conservative and Liberal Poets / 426

On the Moral Value of Romance / 429

On the Word "Nature" / 431

On Letter-Writing / 432

On History / 433

On Revolutions / 437

On Civilization / 439

On the Condition of England / 443

On Co-operation / 444

On Sncial Stability / 445

On Social Powers / 448

On Coleridge and Bentham / 449

On Democracy / 453

On the Electoral Franchise / 459

Speech to the Electors of Westminster / 462

Bibliography / 469 


\section{Introduction}

John Stuart Mill has been described as an "absolutely truthful" man.' He was willing to admit his errors, and also to accept his opponents' truths. Most would agree that his attitude was virtuous, but agreement does not entail understanding. An examination of the relation of truth to virtue casts light not only on Mill but on the whole liberal tradition.

"Absolutely truthful" - the words suggest the kind of unattainable nobility of purpose that graces family escutcheons and disgraces family performances. Why should anyone wish to be absolutely truthful? Common life as well as casuistry shows that truthfulness is not always compatible with mercy and mercy's lesser sister, kindness. Is the man good as well as truthful who tells his cancer-eaten aunt that she is dying, or his adolescent niece that she is ugly? Should a political leader tell his people that they are in great danger of nuclear disintegration, or that they are stupid? The very extremity of such suggestions will show the difficulty of the problem. Hard cases make bad law, it is true (how difficult the word is to avoid), but they test practice. The man who places truthfulness above mercy, and talks of cancer and pimples, is in danger of a smug self-satisfaction that is not far from selfishness and not very far from sadism. In the case of the politician, it might be said that he should tell the truth and let the public vote settle the morality - but let us assume that he is "good" and his politi-

1 John Morley, quoted in Robert Orr, Lord Guthrie: A Memoir (London, 1923), p. 128. 
cal opponent "evil": what proper end would he serve by courting disaster for himself and for his people by telling unwelcome and unpalatable truths? We may go even further, and ask if a spy should tell the truth.

One answer to these problems is that there is an imperative moral injunction, intuitively known and supernaturally imposed, to tell the truth. A famous nineteenth-century controversy between two ministers of religion may illustrate the difficulties here. Charles Kingsley, an Anglican with a dread of Roman Catholicism, accused John Henry Newman, a Catholic convert from Anglicanism, of saying that truth need not always be the major consideration. Whatever the weaknesses of his argument and his understanding, Kingsley had a point. Newman's main concern, as a priest, was the saving of souls; sometimes salvation may require not actually lying, but tempering the truth to the shorn sinner. In effect Newman was saying that we are put on earth not to serve truth, but to serve God. Our highest duty in this respect may be not absolute truth, but relative truth.

Kingsley was an amateur scientist as well as a priest, and his demand for absolute truthfulness reflects his avocation as well as his vocation. In theory at least, scientists should have no trouble in admitting their errors. If a scientist finds, let us say, that he is mistaken in thinking that the forward end of an organism secretes mucus more rapidly than the hind end, he should be willing to admit his error, and begin again at the other end. But in practical life the rules are different. Truth and error are mixed, and compromise is necessary.

For John Stuart Mill, however, in all human concerns the search for truth is primary. It is scarcely an exaggeration to say that his philosophy centres on the search for truth. But the same remark might be made of many philosophers; Mill's view becomes significant only when one looks at the content and development of his thought.

Because both content and development were conditioned by 
Mill's main teachers, his father and Jeremy Bentham, it is important to remember that he belonged to a different generation, even a different century. We often disagree with our parents simply because we grew up in different times. Those who reached maturity during the days of "our gallant ally Russia" find it hard to understand those who reached maturity during the height of the cold war; those who have grown up in jeans cannot see the virtues of trap-door underwear. Each of us wears glasses ground and coloured by our early experience; only a very few are willing, as times change, to change their prescriptions. Mill was one of these few, finding it much easier to sympathize with the hopes and plans of those younger than himself than to share in the feelings and aspirations of his elders. So, while he borrowed and assimilated much from James Mill and Bentham, his was not the age of the philosophes and the French Revolution but of Romanticism and Reform. We find in him, then, a large debt to the past, a strong response to the present, and a devotion to the future.

Mill's early life is sketched out in his Autobiography (see pages $229 \mathrm{ff}$. below). His extraordinary education, initially at the hands of his father, later largely on his own, has been much commented on, and only a few points need making. He himself said that his education, though strenuous, was not one of cram. His father led him to formulate opinions which brought together ideas and facts, and to express those opinions in a persuasive way. He was educated in isolation, except from his younger sisters and brothers, until he went to France at the age of fourteen. Given the circumstances of his nation, class, and era, this isolation did not affect his sympathy with those of his own age; it merely postponed its operation. But it did ensure his dedication to work and study, for he never learned to play. (Before his father, James Mill, is condemned as a domestic tyrant, it should be asked what virtues "learning" to play has.) He was, in his own opinion, singularly awkward in body, slow, for example, in learning to tie shoe-laces. 
His dexterity was reserved for such encounters as those with Lady Spencer, whom he (at age seven) engaged in an argument over the relative merits of Marlborough and Wellington, or with Anne Romilly, whom he a little later referred back to her "authorities" for an opinion. ${ }^{2}$ Apart from disputatiousness, he learned Greek, Latin, mathematics, and a smattering of natural science. He read history and literature, and before the age when children now enter secondary school, was beginning on logic, economics, and less easily defined areas of moral and political science.

In France he learned the language and became acquainted with the literature, while continuing his earlier studies and attending university lectures in logic, zoology, and chemistry. He spent unprofitable hours taking lessons in dancing, riding, and fencing, and profitable ones in botany and music, his lifelong relaxations. On his return to England, aged fifteen, he proceeded to the higher levels of political and philosophical inquiry, and began the study of law. At the same time and for many years, he took a large part in the education of his younger sisters and brothers.

What was the background to this busy foreground? Mill's father, in the first decades of the nineteenth century, was seeking both sustenance for his large family and reform of the power structure in Britain. He was a disciple and ally of Jeremy Bentham, one of the most engaging and productive of British thinkers and eccentrics. Bentham founded the utilitarian school of reformers, whose influence has been felt either directly or indirectly in most of the changes in British administration, law, and politics since the beginning of the nineteenth

2 See Anna J. Mill, ed., John Mill's Boyhood Visit to France, p. xii. In omitting reference to Mill's mother, I am following his own example. She seems to have played a negligible part in his development, and he was virtually estranged from her in 1854 when he wrote the "Early Draft" of his Autobiography, which contains a few uncomplimentary allusions to her. 
century. But the utilitarians, or Philosophic Radicals, as they were for a few years called, made slow headway against those privileges of wealth, family connection, occupation, and education which cohere to form an "establishment". Bentham could have entered the circle of power had he been content to remain at its circumference, but he was too much his own man, too much a rebel, and too independent financially to revolve in others' orbits. He tried, instead, to make the circle square with his ideas of social organization.

Bentham's reforms hinge on one central consideration: all social and individual activity should aim at the greatest possible happiness for everyone. In the common utilitarian phrase, the summum bonum is the "greatest happiness of the greatest number". The philosopher should outline the means; the educational, legal, economic, and political arrangements of society should assist moral changes; the individual should realize the benefit, and help others to it. The program, needless to say, was not to remain in the study; it had to make its way in the world. Bentham was chief designer, but others, and especially James Mill and his son, were to be the propagandists and salesmen.

The major battle was against the entrenched forces of privilege and reaction. During the Napoleonic wars there was little sympathy with reformers; as in other times of real or apparent external crisis, to be out of step with governmental and mass opinion was to be thought dangerous as well as queer. After the peace of 1815 , however, the desire for political reform which had been submerged for a generation surfaced again, buoyed up by the growing economic force of the middle class. Consequently many individuals and groups fought for a realignment of political power. The new forces gathered briefly behind the Philosophic Radicals who, if not representative of the whole nation, presented an organized program consistent with the aims of the middle classes. This program involved a rationalization of political life in accordance with logic and the facts of social power. Its first step was the over- 
throw of privileges and institutions based on tradition, habit, sentiment, and what the Philosophic Radicals called "sinister interest". The true interest of the community as a whole, the "general interest", was ill served by those hereditary leaders whose selfish desire to maintain the status quo became "sinister" when it impeded the development and diffusion of happiness for the nation. Most harmful in the opinion of the Philosophic Radicals were the landowning aristocracy, who stood in the way of industrial progress; the Anglican Church, which stood in the way of intellectual and social progress; the legal system, which stood in the way of equal and rational justice: and especially the political system, which supported and maintained the outmoded power structure. At this last target their main attack was directed, for the reformers saw it as the Achilles' heel of the establishment. If the franchise could be altered to give voice and executive power to the general interest, as embodied in the middle classes, other reforms would become possible. So, while they mounted a continual barrage against economic, legal, and ecclesiastical abuses, their troops gathered under the flag of parliamentary reform, and marched forward to their triumph with the passing of the Reform Act of 1832 .

It was in this cause that John Stuart Mill was enlisted. And his education had been designed to make him an effective warrior and eventual leader. While the ultimate aims of the reformers were constructive, their main task at the moment was demolition, and Mill learned his craft during this phase of the movement. He broke into print in the newspapers and the newly founded utilitarian periodical, the Westminster Review, with attacks on specific abuses and theoretical problems. At the same time he gathered around himself young men of similar temper for formal and informal discussion of public and philosophical questions. In fact, from 1821 to 1826 - that is, from his fifteenth to his twenty-first year - his social and intellectual horizons were those of the Philosophic Radicals.

Here the analysis of his quest for truth may be seen to origi- 
nate. Any attack upon an established system gains strength from a coherent and ordered set of principles. This the Benthamite philosophy possessed to an extreme degree. As will be seen by reference to Mill's account of the charms Bentham's philosophy held for him (pp. 255 ff. below), the traditional British structure, when compared to the clear and rational Benthamite alternative, appeared to be founded on systematic chicanery, obscurantism, and exploitation. It was a living, flourishing lie. Bentham's analysis of moral motivation, strengthened by David Ricardo's analysis of economic motivation and by James Mill's analysis of the mind, pointed to a realization of truth. The Philosophic Radicals' program, in their view, was an honest means to a rational goal. Their positive proposals, of course, had to remain theoretical, for they had not been tried; their comprehensiveness, however, was a guarantee of their practicability, and the only guarantee possible. A theory, James Mill insisted, could not be contradicted by practice if it was a true theory.

This explanation satisfied the young John Mill until his feelings forced a re-examination of the Benthamite program. In a famous passage in his Autobiography (page 280 below), he tells how his desire failed when he admitted that if all the reforms for which he was striving were realized, he would not be happy. The experience was devastating for obvious reasons, and also because the whole aim and purpose of utilitarianism is happiness. He had been taught to despise the feelings as transitory, fluctuating, and idiosyncratic, but he could not deny their force. He also had been taught never to overlook difficulties but to pursue them to their sources and struggle with them until they became strengths. And so he did, but the process was protracted and tormenting. There are many explanations of his depression: he was young, over-worked, under the domination of his father, underdeveloped emotionally, ignorant of other people, starved of sympathy. ${ }^{3}$ None of these

3 Accounts based on one or more of these factors may be found in the bibliography under Levi, Stillinger, Packe, and Robson. 
can be denied importance, but one is of special importance here: his inability to connect intellect and emotion. The Benthamite view of man must, he saw, be faulty, for even if he himself was a flawed specimen of humanity, the view must include him. He was convinced of the rational truth of the system, but he was not adequately motivated by his conviction. If the practice failed, could the theory be true? Or is there a necessary gap between rational theory and living practice?

Although he had read and heard attacks upon utilitarianism, he had always looked upon them as a boxer looks upon his opponent's right hook-something to be countered and not persuaded by. Now his defences were down, and the valid strength of the opposition was brought home to him not long after the onset of his depression. In 1829 Thomas B. Macaulay published three devastating attacks on James Mill's political and ethical views. Basically, Macaulay accused James Mill of assuming that he knew everything about man as a political and moral being, and then arguing deductively from the assumptions without bothering to check his deductions against common knowledge of human behaviour. Mill's conclusions, Macaulay affirmed, were at variance with the most obvious facts, and would be very dangerous in practice, were it not that they were so clearly untrue that there was no danger of their being put into practice.

John Stuart Mill never could admit the gravamen of Macaulay's accusation, for he was a loyal son, and though his faith in Philosophic Radicalism had been shaken, it had not fallen. None the less he pondered deeply, and began the train of investigation that led, in 1843 , to the publication of his monumental System of Logic. In this work, for the first time, there is a serious attempt to see the relative values and uses of both deductive and inductive logic, and a further attempt to estimate the place of both in those sciences which deal with individual and group behaviour. The important conclusion to his discussion of method in the moral and social sciences may be 
seen below (pp. 343-55). Its formal and abstract tone, however, disguises the weight of personal experience lying behind it.

Mill had been partly prepared for the argument of Macaulay by his encounter in his early twenties with the thought of Coleridge and the poetry of Wordsworth. Both had led him to see that beliefs based on common and continuing human experience have a kind of validity not found in beliefs based on abstract thought. He began to look to the past and to aged institutions, not for examples of folly and crime but for lessons in adjustment to experience. Similarly he began to find in literature, as well as in history, evidence of human suffering and glory that no true philosophy can ignore.

In these same years he met members of the French SaintSimonian sect, who were preaching a new social order based on love and organized on justice. Their views were closer to the socialism of Robert Owen than to Benthamism, although they recognized the essential role of the industrialist. They also reinforced for him one of the lessons of Coleridge, arguing that the present age of social and intellectual turmoil and agonized inquiry would end only when a new organic relation developed among men.

Having given up the dogmatism of the Philosophic Radicals, Mill would not accept that of the Saint-Simonians, which was similarly tainted with unsteady assumptions. His early enthusiasm, however, immoderately expressed in a series of articles called "The Spirit of the Age" (1831), brought him into contact with yet another important contributor to Victorian thought, Thomas Carlyle. In the correspondence between Mill and Carlyle 4 is to be found the best evidence of Mill's development in this transitional period. For the student of his thought,

4 See Francis E. Mineka, ed., The Earlier Letters, in Collected Works of Mill, vol. XII (Toronto, 1963), and Alexander Carlyle, ed., Letters of Thomas Carlyle to John Stuart Mill, John Sterling, and Robert Browning (London, 1923). 
the most interesting of the many topics touched on in this correspondence is the distinction between the "Artist" and the "Logician". Both, in Mill's judgment, are concerned with the truth; the Artist or Poet (Carlyle), however, can often immediately perceive what the Logician (Mill) must diligently strive to prove. But both have an educative function, and Mill's increasing confidence can be seen in his assertion that in the present, prosaic state of affairs, the Logician can more easily find an audience than the Poet, and so be more useful.5 Mill clearly felt that only rational persuasion was finally valuable; equally clearly he now saw that more than rational persuasion was necessary for moral action.

Three other important influences on Mill can here only be mentioned. His intense interest in French thought led him in the 1830 s and 1840 s to examine carefully and praise highly the work of Alexis de Tocqueville, the prescient commentator on American democracy, and of Auguste Comte, the father of sociology, who began as a disciple of Saint-Simon. Both taught him important lessons about method and contributed largely to his investigation of the grounds of true belief in moral, political, and social questions. A younger disciple of Mill, Alexander Bain, while he contributed less early and less spectacularly to Mill's thought, worked carefully over his Logic with him, adding examples and suggesting alterations, and in general supported his philosophical positions. Mill eventually differed widely from Comte, as he did from Carlyle, but he retained his admiration for de Tocqueville and Bain throughout his life.

In many ways the most important event of these early years was Mill's falling in love (about 1830) with Harriet Taylor, the beautiful wife of a London wholesale merchant, who had three young children, a sharp tongue, and unfulfilled longings for intellectual achievement. Mill became her mentor and her

5 A fuller examination of this and related topics will be found in Robson, "John Stuart Mill's Theory of Poetry". 
slave; she eventually shared in his writings, which he thought were hers as much as his. Her husband died in 1849 , and they were married in 1851. Their relations, intense but ever Platonic, provide a story of sad fascination; again one aspect stands out for my present purposes. ${ }^{6}$ Mill, it will be recalled, thought himself clumsy; his uncertainty extended to a wide area of practical affairs. He also, as his correspondence with Carlyle shows, thought himself deficient in penetrating the obscuring clouds of qualifications and contingencies; he longed for a vivid enthusiasm, but could not engender one in himself or in others. His greatest strengths lay in testing theories, in evaluating and comparing, in the study and practice of logic and method. Harriet's capabilities, he thought, perfectly compensated for his deficiencies. ${ }^{7}$ In a passage given in full below (pp. 316-17), he says:

With those who, like all the best and wisest of mankind, are dissatisfied with human life as it is, and whose feelings are wholly identified with its radical amendment, there are two main regions of thought. One is the region of ultimate aims; the constituent elements of the highest realizable ideal of human life. The other is that of the immediately useful and practically attainable. In both these departments, I have acquired more from [my wife's] teaching, than from all other sources taken together. And, to say truth, it is in these two extremes principally, that real certainty lies. My own strength lay wholly in the uncertain and slippery intermediate region, that of theory, or moral and political science. . . .

This comment, I believe, has not been taken seriously

6 The fullest accounts of their relations are in the items under Hayek and Packe in the bibliography; see also, however, the item under Stillinger; also F. E. Mineka, "The Autobiography and the Lady", University of Toronto Quarterly, 32 (1963), 301-6; and H. O. Pappe, John Stuart Mill and the Harriet Taylor Myth (Melbourne, 1960).

7 In the following account I leave out of court the hyperbole in Mill's estimate of his wife's abilities; the passages below, and the works cited in the previous note, give the evidence. 
enough, nor has it been seen in relation to the passage from the Logic mentioned above (see page 346), where Mill argues that in all properly conceived human endeavour there are three operations, often mixed in fact but separable in theory. First there is an attempt to define an end which will satisfy the needs and desires involved. Second there is a discernment of means to the end. Finally there is an application of the means to realize the end. The same procedures apply to making a canal or a constitution, a missile or a medicine. Just as operations are often mixed in practice though separable in theory, so the men who perform them may be described as distinct, though often one man will act in all three ways.

When this passage is placed next to the one quoted above from the Autobiography they cast mutual light upon each other. In discerning the ideal, Mill says, his wife was supreme. Here "real certainty" lies, because here difficulties are forgotten and dreams indulged. Here, if you like, is the "ivory tower" so much satirized and feared by "practical" men, but here also is the impetus to change, the vision to transform, and the spark to give life. Mill spent much ink, especially early in life, attacking practical men as the worst of theorists, and his attack has been taken to imply an ignorance, even an arrogance, concerning the difficulties of implementing policy. Actually there is plenty of evidence to show his awareness of these difficulties (see, for example, pp. 264-5 below). His main concern was to keep the practical man in the area of practice. This is the third area described above, and in it also Mill finds "real certainty". It is not easy to see exactly what he means by saying this, except that one can tell whether or not a program is working by examining the immediate results. If one is electing a representative or seducing a woman, one can soon have real certainty about success or failure. There can be no certainty about success in advance, of course, for in these cases, as in many others, especially in the democratic society Mill posits, persuasion is essential.

Knowing himself deficient in both the initial and final 
stages, Mill saw - and most would agree, correctly saw - his own strength in the intermediate stage of devising means. But further explanation is here needed. Mill assigned the first and third stages to the "Artist". (He uses the word not in the same sense here as in the discussion with Carlyle, but there are similarities between the two kinds of Artist.) The middle stage belongs to the "Scientist". His activity is not, in this context, "pure"; that is, it is directed towards a given end and is not disinterested. Some of Mill's own work, especially in logic and economics, is pure and theoretical, but he was first and last a reformer, and both his System of Logic and his Principles of Political Economy are measured polemics in support of his ethical and social ideals.

It is important also to notice that the devising of means by the "Scientist" and the application of them by the "Artist" are not properly discrete. A hypothetical case will illustrate. Suppose that a young man, living in one city, finds work in another fifty miles away. His aim (as Artist) is to find transportation which will enable him to make the journey twice each day. How shall he do it? (The Scientist's work begins.) There is no satisfactory bus or train available, so he decides to obtain a car. First, however, he must learn to drive. Second, he cannot afford to buy a car, because all his money will be spent on driving lessons. But his father has a large sum of money, which cannot be borrowed and so must be stolen. Here a practical difficulty intervenes, for the father is stronger than the son and will beat him mercilessly if he catches him. If the son succeeds in surmounting this obstacle, there is still another, which might also be called practical but which relates more to the end than the means. If he escapes with the money and buys the car, the father will have him arrested and imprisoned, and so he will not be able to hold the job which made the car necessary in the first place.

In short, problems not strictly "Scientific" must be solved before practice (the second area of "Art") can begin. The means must be tested against the readiness of the people (can 
the young man drive?), against the practical difficulties (who is stronger?), and against the end (if implementation of the means puts him in prison, he cannot achieve his purpose of driving to work each day). Whether or not the means are put into practice at all depends - and Mill is clear about this on a successful passing of these tests, and it makes no difference whether the man who imposes them is called Scientist or Artist. If, when Mill denied himself practical competence, he was referring to practical testing, he was certainly under-estimating his powers, for one of the strongest marks of his thought is his constant awareness that schemes must be in accord with people's capabilities, must be feasible, and must be consonant with their ends - that is, in most cases, must be moral.

It is safe when thinking of Mill to consider that they must always be moral, for his thought has a constant moral reference. He began as a utilitarian, and partly in spite of and partly because of his differences from Bentham, he ended as one. That is, he believed that all actions should conduce to the greatest happiness of the greatest number, and that happiness is to be measured by the presence of pleasure and the absence of pain. The best summary of his views is found in Utilitarianism and so need not be given here. That work, however, by philosophic standards is brief and unsubtle, and it also suffers from having been written for a periodical. A few comments are therefore necessary.

First, in spite of his differences from Bentham, Mill adhered fairly closely to the "felicific calculus" which Bentham devised as an ethical guide. In Bentham's view, all pleasures can be measured by simple criteria: are they intense, durable, certain, and quick to follow actions, fruitful of other pleasures, not mixed with pain, and do they extend to other people? We should seek those pleasures which satisfy all these tests. Admitting at the same time that such pleasures are extremely rare, we should measure the pleasures we can reasonably expect to attain against one another. The great virtue of this cal- 
culus to the utilitarian is that it makes moral judgments "objective", that is, not idiosyncratic and variable.

Mill was attracted strongly to this position, and most of his comments on Bentham in fact dwell on this point. It has been thought odd, therefore, that in Utilitarianism he apparently gives it up and introduces what seems to be a subjective element, saying that pleasures can be divided into "higher" and "lower". If they can be so divided, not according to a Benthamite quantitative measurement but according to a qualitative one, the whole objective structure collapses. Mill attempts to save it by saying that the judgment of "higher" should be placed in the hands of the wisest of mankind, who have known all pleasures and so can judge their relative worth. But he fails on two counts. First, those who have known all pleasures are not necessarily the wisest and best, and may prefer what Mill (who had not tried and known all) would certainly consider lower pleasures. Even if they do not prefer what Mill would disapprove, the test proves nothing, for we are in effect asking those who prefer higher pleasures to tell us which pleasures are higher. Second, a study of Mill's thought shows that for him the higher pleasures are just those that would appear by the Benthamite calculus to be most pleasurable-roughly, "mental" as opposed to "physical" pleasures - and there is no point at all in introducing the qualitative distinction.

A second difficulty in Utilitarianism has occasioned an equal amount of controversy, and equally reveals, if not a flaw in Mill's position, at least carelessness in expression. In trying to explain why we should desire the pleasurable, Mill apparently forgets what he elsewhere shows ample evidence of knowing, that there is a difference between judgments of what is and of what ought to be - that is, he is guilty of what is known as the naturalistic fallacy. In the crucial passage (pp. 192-3 below), he uses a suspect analogy to make his point: just as things which are seen are visible, so things which are desired are desirable. But the specifically moral element is here illegitimately smuggled in, for all things which are desired 
in fact are not (by any ethical criterion) desirable. This flaw was pointed out to Mill by his German translator, Theodor Gomperz, but Mill shrugged off the matter, saying that Gomperz could, if he wished, alter the passage in translation. What his reasoning was we do not know; his defence clearly could rest on the title of the chapter in which the argument occurs, "Of What Sort of Proof.the Principle of Utility is Susceptible". He had already said (p. 154) that ultimate ends are not amenable to direct proof. Here he shifts from logical proof to psychological persuasion, and would seem to be bearing out a distinction brilliantly drawn by Newman between "certainty" (a quality of propositions) and "certitude" (a quality of mind).

These matters are not quibbles, but they are not central to a discussion of Mill's ethic. That clearly marks him off from Bentham is his insistence on the personal and individual element in moral behaviour. Bentham was most interested in designing a "good" society. His penal reforms, for instance, were intended "to grind rogues honest" by the application of external sanctions, for the good of the community. Mill, on the other hand, was most interested in developing "good" individuals. He had learned from his own hard experience that motives cannot be drilled into human beings. It may be possible to make people habitually perform acts conducive to the happiness of society, but if such acts are motivated only by a rational calculation of the main chance, they cannot properly be called moral. The living assent of the actor must go with the act. To reduce a complicated question to a sentence, I may say that Mill made the greatest happiness of the greatest number not only the end and test of actions but their motive as well. By the cultivation of imaginative sympathy one learns to place oneself in the position of others, learns to love them, and finally learns to place their happiness above one's own. Or, more properly, one ignores one's own happiness, for to ask the question "Am I happy?" is to invite constant disappointment and misery. Personal happiness is a by-product of moral behaviour. (See p. 286.) 
Mill worked out his "anti-self-consciousness" theory in conjunction with another which he attributes to Goethe: "manysidedness". His own teachers had concentrated on reason, believing emotion to be unreliable and aesthetics to be irrelevant. But Mill, learning to feel sympathy and to love beauty, saw the pressing utility of what Matthew Arnold would call a general and harmonious expansion of human powers. The range of human needs and abilities is wide, and the joyful acceptance of the full range is necessary to moral development. The pattern of formal education which conduces to this development is sketched out by Mill in his Inaugural Address (pp. 379ff. below); the individual and social urgency is shown throughout the classic argument of On Liberty. And finally it is in this context that his search for truth must be considered.

Why should a search for happiness involve a search for truth? The connection is certainly less obvious than that, to return to an earlier instance, between salvation and truth. But for Mill the connection between utility and truth is intimate and necessary. As an empiricist, he holds that all our knowledge comes initially through the senses. We gradually build up notions, complicated ideas, and beliefs, making up our worlds of the building blocks supplied by sense experience, according to the laws of mental association. There are no certain and blinding intuitions divorced from experience; we have no super- or extra-human ways of apprehending. The path of knowledge is therefore painstakingly difficult; enlightenment is gradual. But the search is obligatory, for we cannot satisfy our needs and desires without knowing what they are, what will satisfy them, and to what extent they can be satisfied. In short, happiness depends on a wide acquaintance with experience.

The inductive philosophy here implied is fact-hungry: as a system it has elastic walls, infinitely extensible to accommodate ever-increasing knowledge. Nothing known or knowable to man can be excluded, for all may be useful in promoting his happiness. Our beliefs are generalizations founded on experi- 
ence and tested against experience. As such, they can never be known to be true, for we can never be sure that all relevant observations have been made or that the observations which have been made are correct and correctly interpreted. For example, today I saw a black crow; yesterday I saw a black crow; actually I have never seen, read about, or heard of, any crow that was not black. Now (without defining a crow as a black bird, and so making the connection necessary) I build a generalization on my observations: all crows are black. This is my belief. Then I visit Mississippi and see a white crow, and my belief is shattered. We know by definition that all bachelors are unmarried men; but can we be certain that all bachelors are moral reprobates, no matter how many of them give evidence of being so? Can we be absolutely certain that there will be a sunrise tomorrow? Sense experience can never produce unqualifiable beliefs. For Mill this is an inescapable part of the human condition, and he even tries to make its unpleasantness a virtue by agreeing with the common Victorian attitude that strenuous endeavour after an unattainable perfection is the proper activity for men: in Browning's words, "a man's reach should exceed his grasp, or what's a heaven for?"

As our store of information increases, our beliefs are strengthened. And the word "true", in Mill's system, can be properly applied only to generalizations, and not to "facts". So the word is qualifiable: beliefs, because they are generalizations, can be made "truer" by taking into account more information and by testing that information by the canons of inductive proof (as outlined in Book III of Mill's Logic). In discussing the work on Plato by his friend George Grote, Mill argues that a belief or opinion is

relative not only to the believing mind, but to something else - namely the matter of fact which the belief is about. The truth of the belief is its agreement with that fact. . . . No one means anything by truth, but the agreement of a belief with the fact which it purports to represent. ${ }^{\mathrm{s}}$

8 Dissertations and Discussions, vu.. III (London, 1867), pp. 357-8. 
It should be noted that the agreement is not between belief and objective reality. As an empiricist, Mill will not look beyond sense experience; the objective world cannot be known to be known. The passage quoted above continues:

We grant that, according to the philosophy which we hold in common with $\mathrm{Mr}$. Grote, the fact itself, if knowable to us, is relative to our perceptions - to our senses or our internal consciousness; and our opinion about the fact is so too; but the truth of the opinion is a question of relation between these two relatives, one of which is an objective standard for the other.

This attitude towards truth, although it abandons certainty, need not be paralysing. Our lives are guided by approximations, and the more accurate the approximations the better will our chosen means satisfy our desired ends. In the process, we must not limit ourselves to preconceptions and established opinions. As Mill says in one of his early speeches, the "good of mankind requires that nothing should be believed until the question be first asked, what evidence there is for it." Modified by time and for the occasion, the same view is echoed in his Inaugural Address: "The most incessant occupation of the human intellect throughout life is the ascertainment of truth. We are always needing to know what is actually true about something or other." (See p. 396 below.)

We must therefore be eclectic, learning from our own experience, from our allies, and from our opponents. In ethics, for example, Mill insists that there are major areas of agreement among different systems, and the agreement can be made productive if it is not lost in fruitless controversy. Another necessity, of course, is freedom. The lessons of On Liberty are reflected throughout Mill's writings as he argues time and again for freedom to experiment, freedom to question,

9 "Speech on the Church", in Autobiography, ed. H. J. Laski (London, 1924), p. 332. 
freedom to find. There is a tension in On Liberty between two views of the virtue of freedom: on the one hand Mill is assuming that there is a basic need in men to fulfil themselves; on the other hand he assumes that this fulfilment is part of the general progress towards social utility. The second of these is more in tune with his attitudes elsewhere, but the tension is not damaging here, for both views support the general approach to truth. The danger he exposed himself to has been exploited by those who, seizing on his insistence that liberty is an essential human desire, have argued that he supports eccentricity and licence. Again one may point to a title in defence of Mill: the part of On Liberty which leaves him open to this attack occurs in a chapter entitled "On Individuality, as One of the Elements of Well-Being". It is a very important element, but it is only one.

Just as freedom and the search for truth are necessary parts of the search for happiness, so are other goals for which Mill argues. One of the best examples is his lifelong attempt to win equality for women. To deny them equality is to shut off one half of the human race from self-development, and to deprive the other half of needful experience which it cannot have, yet cannot well do without. It is also unjust, and justice is part of utility.

His discussions of democracy and socialism are betterknown instances. His position cannot be fully understood until one realizes that political and economic equality are for him legitimate but not ultimate goals. He was throughout life a proponent of democracy, but he was convinced that a realistic analysis of the dangers of democracy was necessary before its triumph could conduce to the highest utility. Of socialism he was less sure. He spoke out strongly against state socialism, but gave full support to socialistic experiments conducted on a voluntary basis. He especially favoured co-operative ventures, because he believed that only trial - with its possibilities for error and disappuintment as well as truth and happinesscould provide trustworthy evidence about social and economic 
arrangements. It should be emphasized that in both these areas, as elsewhere, he is concerned with the tests described above: granted that the aims of democrats and socialists are desirable, are their means suitable? Are the people ready to implement and maintain the necessary institutions and habits? Are the means in accordance with what we know of man and nature? And finally, are they moral?

In all that has been said, it will be seen that there is implicit a doctrine of moral progress, both individual and social. This is not to say that Mill naively held that every day in every way things are getting better and better. The road of individual improvement is a tortuous one, full of pot-holes and wrong turnings. Moreover, it cannot be converted into a super-highway, carrying all who enter from misery to happiness at reckless speeds. Each must learn the route, pay tolls, study and enjoy the scenery, and travel at his own rate. Moral behaviour is not inheritable, and the children of careful drivers will continue to take the hotrod trail to perdition. But though morality begins anew with each child, moral information and attitudes accumulate through time, and education, Mill believed, could make it easier for the individual to become moral. ${ }^{10}$ Still the onus remains on the person who acts, the moral agent: it is good for him to be trained to behave well; it is better for him to learn to behave well; it is best for him to understand why he should behave well, and so involve his will in that understanding that his future good conduct is ensured. It cannot be fully ensured, of course, for the will is errant, circumstances are frustrating, and matter is intractable. (These are some of the secular versions of original sin.)

10 Here and at other points, there are instructive parallels between Mill's ethical position and that of T. H. Huxley, who similarly attacks "mere" practical men, adopts a similar attitude towards altruism and the growth of conscience, and rejects Nature as an ethical norm. (On the last question, see pp. 431-2 below.) 
Here yet another difference between Mill and Bentham is important. Bentham, it will be recalled, was primarily concerned with objective evaluation, and looked not to the agent but to the act. An act is good or bad according to its consequences, both foreseen and unforeseen. But the agent, Mill was concerned to point out, cannot be judged by the actual consequences of his actions. He should learn to avoid behaviour which has in the past led to unhappiness for himself and others, and to cultivate habits which have stood the moral test of time, but he must be judged in any particular case by his intentions.

Though as he grew older Mill became less confident about the rate of progress, he continued to believe that time and effort could breed individuals of superior morality. It may be questioned whether his view has proved its validity in a century which has raised such monstrous barriers in the path of hope. About social progress as he outlined it, however, it may be said without serious qualification that he was right. There is now far more concern for social justice, far better machinery for preventing and aiding distress, far more effective private and public agencies for humanitarian ends, than there were in his day. In this respect, at least, one may say that the search for truth, if it has not made us free, has at least made us happier. 
xxix

\section{Note on the Text}

Although Mill revised many of his works carefully from edition to edition, he left $O n$ Liberty in its original version, probably because he felt it so much a "joint production" with his wife that alterations would be improper. The text in this volume, therefore, is that of the first edition (1859). Utilitarianism was not much revised, but the alterations in the last chapter are significant enough to warrant printing the final text prepared by Mill for the third edition (1867). For these works, as indeed for most of Mill's writings, there is no manuscript. The text of the Autobiography is taken from the Columbia edition (1924), which is printed from Mill's own holograph manuscript; verbal corrections have been made from the manuscript. The selections from the System of Logic and the Principles of Political Economy are taken, respectively, from the eighth (1872) and seventh (1871) editions, the last in Mill's lifetime. The selections from the Inaugural Address and The Subjection of Women are both taken from the first editions (1867 and 1869). Details concerning the sources of the other selections are found in footnotes to their titles. As the selections do not have titles, these have been supplied; the dates added are those of first publication. In all cases, typographical errors have been corrected, and spelling and italicization normalized. Punctuation has been modernized in a few places. In the selections a short ellipsis is indicated in the normal way by three dots, and a longer ellipsis by a row of seven dots.

I should like to thank the British Library of Political and 
Economic Science for permission to print part of Mill's unpublished speech to the electors of Westminster; the Columbia University Press for permission to print the selections from the Autobiography; and the University of Toronto Press for permission to quote the passage from the letter to Sterling ("On Letter-Writing") from the Collected Works of J. S. Mill. 


\section{John Stuart Mill}

\section{B I O G R A P H I C A L D A T A}

1806 Born May 20, in London.

1809 Period of intensive education at home, which continued until his departure for France in 1820.

1820-1 Year in France, in the household of Sir Samuel Bentham.

1822 Studied law. First publications in newspapers.

1823 Began career in East India Company.

1823-9 Period of study with friends, in "Utilitarian Society" and at Grote's house.

1824 Founding of Westminster Review, for which he wrote until 1828.

1825 Began editing Bentham's Rationale of Judicial Evidence (published 1827). Helped found the London Debating Society.

1826-7 "Mental crisis".

1830 Met Harriet Hardy Taylor. In Paris during French Revolution; began to write extensively on French political affairs.

1832 Death of Bentham. Passing of first Reform Act.

1835 Founded and edited the London Review, which continued as London and Westminster Review until 1840.

1836 Death of James Mill.

1843 Publication of $A$ System of Logic (eight editions in his lifetime). 
1844 Publication of Essays on Some Unsettled Questions of Political Economy.

1848 Publication of Principles of Political Economy (seven editions in his lifetime).

1851 Married Harriet Taylor, whose husband John had died in 1849.

1854 From December until June 1855 , on extended holiday for health in Italy and Greece.

1856 Became Chief Examiner of the India Correspondence in the East India Company, as his father had formerly been.

1858 Retirement from East India Company when taken over by the Crown. Death of Harriet Taylor Mill in Avignon.

1859 Until his death, spent about one-half of each year in Avignon. Published On Liberty, the first two volumes of Dissertations and Discussions, and Thoughts on Parliamentary Reform.

1861 Published Considerations on Representative Government and Utilitarianism (in Fraser's Magazine; published as book first in 1863).

1865 Elected Member of Parliament for Westminster. Published An Examination of Sir William Hamilton's Philosophy and Auguste Comte and Positivism.

1867 Published Volume III of Dissertations and Discussions, and Inaugural Address at St. Andrews University, having been elected Rector in the previous year. Passing of second Reform Act, which Mill had tried to amend to allow women to vote and to provide for proportional representation.

1868 Defeated in parliamentary election.

1869 Published The Subjection of Women.

1870 Published Chapters and Speeches on the Irish Land Question. 
1873 Died May 7, in Avignon.

Posthumous publications (all edited by his stepdaughter, Helen Taylor):

1873 Autobiography.

1874 Three Essays on Religion ("Nature", "The Utility of Religion", and "Theism").

1875 Volume IV of Dissertations and Discussions.

1879 Chapters on Socialism. 